\title{
Base Erosion and Profit Shifting (BEPS): Pros and Cons between Companies and Governments
}

\author{
Joni $^{*}$, Handryno ${ }^{* *}$ \\ ${ }^{*}$ Institut Ilmu Sosial dan Manajemen, Sekolah Tinggi Ilmu Administrasi Mandala Indonesia (STIAMI) \\ DOI: 10.29322/IJSRP.11.01.2021.p10957 \\ http://dx.doi.org/10.29322/IJSRP.11.01.2021.p10957
}

\begin{abstract}
The purpose of this study was to evaluate the pros and cons between multinational companies and the government on Base Erosion and Profit Shifting (BEPS). The research method used is a qualitative method. This method is used to evaluate cases. This research will discuss about Base Erosion and Profit Shifting (BEPS), the cause and effect of the pros and cons between multinational companies and the government and discuss suitable solutions to overcome these pros and cons. In addition, researchers also offer an idea that is expected to be a solution. The idea is to allocate corporate income tax rates to dividend income tax. Corporate income tax in Indonesia is $25 \%$ and the dividend income tax is $10 \%$. If the tax rate is allocated, such as corporate income tax of $15 \%$ and dividend income tax of
\end{abstract}

\section{INTRODUTION}

The researcher got the idea above when the researcher read the cases of Base Erosion and Profit Shifting (BEPS) and found that almost all of the articles had a negative view about Base Erosion and Profit Shifting (BEPS). Even though the concept of making Base Erosion and Profit Shifting (BEPS) itself is positive and is expected to benefit all parties. Therefore, researchers are interested in making an article with a different view from the previous article.

This article will discuss the cause and effect of the pros and cons between multinational companies and governments regarding Base Erosion and Profit Shifting (BEPS). In addition, this article also discusses the positive side of Base Erosion and Profit Shifting (BEPS) that can be applied in Indonesia.

\section{METHOD}

Researchers used qualitative research methods as a method to evaluate cases and used some descriptive estimation data to explain the overall concept.
$20 \%$, then multinational companies will tend to allocate their corporate profits from other countries to our country. The allocated profit will increase the payable tax and ultimately increase the State's income. According to the statement, it can be concluded that company profits have a positive effect on state revenues, so that if the government can make good use of Base Erosion and Profit Shifting (BEPS), then Base Erosion and Profit Shifting (BEPS) can have a positive impact on our country.

Index Terms - BEPS, Multinational Companies, Government, Corporate Income Tax, Dividend Income Tax.

\section{BASE EROSION AND PROFIT SHIFTING (BEPS)}

Base Erosion and Profit Shifting (BEPS) is a tax planning strategy that takes advantage of the gaps or weaknesses contained in the domestic tax law to eliminate or divert these profits to other countries that have lower tax rates (Rakhmindyarto, 2013).

Base Erosion and Profit Shifting (BEPS) was founded by the Organization for Economic Coorperation and Development (OECD) together with the G20 in 2013.The aim of establishing Base Erosion and Profit Shifting (BEPS) is to prevent unfair shifts in profits between countries or multinational (Johanna \& Valderrama, 2020).

Many countries in the world including the G20 countries apply high tariffs. This causes these countries to be most vulnerable to the impact of Base Erosion and Profit Shifting (BEPS) practices carried out by multinational companies. This can be seen from the amount of corporate tax rates for all G20 member countries which are listed in the table below (Arifin, 2014). 


\begin{tabular}{|r|l|r|r|r|}
\hline \multicolumn{5}{|c|}{ G20 Tax Comparison } \\
\hline \multirow{2}{*}{ No. } & \multirow{2}{*}{ Country } & \multicolumn{1}{|c|}{ Corporate Income } & Capital Gain & \multicolumn{1}{c|}{ Branch } \\
\cline { 2 - 5 } & & \multicolumn{1}{|c|}{ Tax Rate (\%) } & Tax Rate (\%) & Tax Rate (\%) \\
\hline 1 & Argentina & 35 & 35 & 35 \\
\hline 2 & Australia & 20 & 30 & 30 \\
\hline 3 & Brazil & 15 & 15 & 15 \\
\hline 4 & Canada & 25 & 7.5 & 15 \\
\hline 5 & China & $331 / 3$ & $0 / 15 / 331 / 3$ & $331 / 3$ \\
\hline 6 & France & 15 & 15 & 15 \\
\hline 7 & Germany & 25 & & \\
\hline 8 & Indonesia & 30 & 20 & 20 \\
\hline 9 & India & 27.5 & $1.37 / 27.5$ & 27.5 \\
\hline 10 & Italy & 25.5 & 25.5 & 25.5 \\
\hline 11 & Japan & 22 & 22 & 22 \\
\hline 12 & Republic of Korea & 30 & 30 & 30 \\
\hline 13 & Mexico & $5 / 20$ & $5 / 20$ & $5 / 20$ \\
\hline 14 & Russia & 30 to 85 & 20 & \\
\hline 15 & Saudi Arabia & 28 & 18.65 & 28 \\
\hline 16 & South Africa & 20 & 20 & 20 \\
\hline 17 & Turkey & 24 & 24 & 24 \\
\hline 18 & United Kingdom & 35 & 35 & 35 \\
\hline 19 & United States & 24 & 24 \\
\hline 20 & European Union & & & \\
\hline & & & & \\
\hline
\end{tabular}

In general, the practice of Base Erosion and Profit Shifting (BEPS) by multinational companies has the following impacts (Rakhmindyarto, 2013).

1. There is distortion of competition, the practice of Base Erosion and Profit Shifting (BEPS) will be more profitable for multinational companies than domestic companies in terms of competitive advantage. This is because the opportunities from Base Erosion and Profit Shifting (BEPS) can save more taxes with high profits.

2. Causing inefficiency in resource allocation by distorting investment decisions towards businesses that have low returns before tax, but have high returns after tax.

3. The practice of Base Erosion and Profit Shifting (BEPS) will discourage taxpayers from not complying with their tax obligations when they see multinational companies that do not comply or avoid tax obligations.

\section{BASE EROSION AND PROFIT SHIFTING (BEPS) ACTION PLAN}

To overcome the impacts, the Organization for Economic Coorperation and Development (OECD) together with the G20 created a Base Erosion and Profit Shifting (BEPS) Action Plan aimed at addressing the concerns of many countries due to the problem of reducing state revenue from taxes due to aggressive tax planning carried out by multinational companies (Arifin, 2014). In general, the Base Erosion and Profit Shifting (BEPS) action plan discusses 4 main principles:

a. Build corporate income tax coherence internationally by neutralizing the impact of different tax rates, strengthening regulatory oversight of foreign companies, limiting tax revenue reductions, and more effectively combating adverse tax practices.

For corporate or taxpayers, especially multinational companies, Base Erosion and Profit Shifting (BEPS) is a positive thing. This is because the application of Base Erosion and Profit Shifting (BEPS) will save taxes and increase company profits. As for the government, Base Erosion and Profit Shifting (BEPS) is a negative thing. This is because the application of Base Erosion and Profit Shifting (BEPS) will reduce State revenues for countries that have high tax rates. Therefore, there are pros and cons between multinational companies and the government.

\section{BASE EROSION AND PROFIT SHIFTING (BEPS) PRACTICES}


the concerns of many countries due to the Base Erosion and Profit Shifting (BEPS) problem:

1. Action 1: Addressing the Tax Challenges of the Digital Economy. The digital economy is an economic transformative process through information and communication technology (ICT). The goal of action 1 of the BEPS Action Plan to address the challenge of the digital economy tax. The Task Force on the Digital Economy (TFDE) is a subsidiary of the Committee on Fiscal Affairs (CFA) made up of non-OECD G20 countries. The Task Force on the Digital Economy (TFDE) is an agency that functions to monitor business developments and the added value resulting from digital economy business practices. The Task Force on the Digital Economy (TFDE) will analyze economic data that comes from business, civil society, academia and developing countries. In addition, The Task Force on the Digital Economy (TFDE) also provides extensive stakeholder consultation (OECD, 2015c).

2. Action 2: Neutralize the effects of hybrid mismatch schemes (debt-equity instruments and entities). In action 2 Base Erosion and Profit Shifting (BEPS), the Organization for Economic Coorperation and Development (OECD) recommended 2 things to increase the coherence of international income taxes. First, the Organization for Economic Cooperation and Development (OECD) recommends changes to domestic law. The first recommendation describes the rules for overcoming tax mismatch that arise due to payment instruments made by or to hybrid entities. Second, the Organization for Economic Cooperation and Development (OECD) recommends changes to the OECD Model Tax Convention. The purpose of the second recommendation is to ensure that hybrid instruments, hybrid entities, and entities with two domiciles are not used to obtain undue tax benefits (OECD, 2015b).

3. Action 3: Strengthen controlled foreign company (CFC). Controlled Foreign Company (CFC) is a rule that governs the income tax on a foreign subsidiary that is eligible for taxation. However, some countries do not currently have CFC rules and countries have CFC rules that do not contradict the concept of BEPS comprehensively. Action 3 of the Base Erosion and Profit Shifting (BEPS) Action Plan itself aims to develop the recommendations obtained for the effectiveness of Controlled Foreign
Company (CFC) regulations in dealing with Base Erosion and Profit Shifting (OECD, 2015e).

4. Action 4: Limit base erosion via interest deductions and other financial payments. Action 4 in the Basic Erosion and Profit Shift (BEPS) action plan aims to prevent tax risks arising from improper charges of debt, loans and interest by multinational companies (OECD/G20, 2016).

5. Action 5: Counter harmful tax practices more effectively, taking into account transparency and substance. The Action 5 Report (OECD, 2015) is one of the four minimum standards for BEPS. All BEPS Inclusive members are committed to implementing the minimum standard of Action 5 and participating in peer review. The peer review of Action 5 will be carried out by the Hazardous Tax Practice Forum / FHTP (OECD, 2017b).

6. Action 6: Prevent treaty abuse. The Report on Action 6 in the Basic Erosion and Profit Shift (BEPS) is one of the four in the Basic Erosion and Profit Shift (BEPS) minimum standards. The Action 6 in Basic Erosion and Profit Shifting (BEPS) is about preventing treaty abuse including the case of treaty shopping.(OECD, 2017c).

7. Action 7: Prevent the artificial avoidance of permanent establishment status. Action 7 of Base Erosion and Profit Shifting (BEPS) aims to prevent artificial avoidance with a permanent establishment status in Base Erosion and Profit Shifting (OECD, 2015f).

8. Action 8-10: Assure that transfer pricing outcomes are in line with value creation (intangibles, risks and capital, other high-risk transactions). In general, actions 8-10 have in common the form of oversight of transfer pricing. Action 8 contains prevention of improper transfer pricing because goods are intangible. Action 9 contains prevention of improper transfer pricing due to risk and capital. Action 9 contains prevention of improper transfer pricing due to high-risk transactions (OECD, 2018).

9. Action 11: Establish methodologies to collect and analyze data on BEPS and the actions to address it. Action 11 on Base Erosion and Profit Shifting (BEPS) covers the following: applying a specific methodology to collect and analyze Base Erosion and Profit Shifting (BEPS) data. The Base Erosion and Profit Shifting (BEPS) data can be used to solve problems and cases of Base Erosion and Profit Shifting / BEPS. In particular, to develop indicators of scale and economic impact of Base Erosion and Profit Shifting (BEPS). In addition, 
action 11 also includes monitoring of the tools used for monitoring and evaluating the effectiveness of Base Erosion and Profit Shifting (BEPS) in a sustainable manner (OECD, 2015d).

10. Action 12: Require taxpayers to disclose their aggressive tax planning arrangements. The Lack of knowledge and relevant information about aggressive tax planning is a major threat to tax authorities worldwide. Therefore, relevant information is important in tax risk risk quickly. In Action 12 the Base Erosion and Profit Shifting (BEPS) Action Plan devises a tool to improve the flow of relevant information about tax risk. This information will be communicated to the information to the tax administration and tax policymakers in order to address the associated risks(OECD, 2016b).

11. Action 13: Re-examine transfer pricing documentation. In Action 13 of the Base Erosion and Profit Shifting (BEPS) action plan establishes relevant information to be used to conduct reviews, schedule procedures, summarize peer review reports, process discussions, approve reviews, amendments, interpret and maintain confidentiality of peer review documents. All of these determinations in action 13 are defined by the Inclusive Framework (Inclusive Framework) Base Erosion and Profit Shifting / BEPS (OECD, 2017a).

12. Action 14: Make dispute resolution mechanisms more effective. In Action 14 of the Base Erosion and Profit Shifting (BEPS) action plan, it discusses certainty for taxpayers to resolve disputes effectively. In the Action report 14 of the Base Erosion and Profit Shifting (BEPS) action plan, it contains the commitments of countries regarding the agreement to apply minimum standards in order to resolve disputes in a timely, effective and efficient manner (OECD, 2016a).

13. Action 15: Develop a multilateral instrument. Action 15 of the Base Erosion and Profit Shifting (BEPS) Action Plan for the development of a multilateral instrument. In Action 15, the Basic Action Plan for Erosion and Profit Shifting (BEPS) includes an analysis of tax issues and public international law related to the development of multilateral instruments. This is useful for making it easier for jurisdictions to implement developmental measures that behave with Base Erosion and Profit Shifting (BEPS) work and amend bilateral tax treaties. In addition, interested Parties will develop multilateral instruments designed to provide innovative approaches to international taxation issues and reflect the nature of the evolving global economy and the need to adapt rapidly to this evolution (OECD, 2015a).

\section{BASE EROSION AND PROFIT SHIFTING (BEPS) ISSUES}

Even though the Organization for Economic Coordination and Development (OECD) and the G20 have taken precautions, there are still issues regarding aggressive tax avoidance, such as: the case of Google, Facebook, Starbucks and Amazon. The multinational company did not violate applicable laws, but carried out tax management which led to aggressive tax evasion. This is indeed more of a moral and ethical nature so that it is difficult to make rules and laws. Therefore, it can be said that tax evasion is indeed legal if it is still in accordance with applicable laws (PWC, 2013).

\section{DISCUSSION}

Based on the researcher's view, multinational companies and governments actually have the same goal. If the company has high profits, then the company will also generate high taxes and increase state revenue. According to statement, it can be concluded that company profits have a positive effect on State revenues, so that if the government can take advantage of Base Erosion and Profit Shifting (BEPS) in increasing company profits, it should increase State revenues too.

To realize this, the researcher offers an idea, that is allocate corporate income tax rates to dividend income tax. The corporate income tax in Indonesia is $25 \%$ and the final dividend income tax is $10 \%$. If the tax rates are allocated, such as corporate income tax of $15 \%$ and final dividend income tax of $20 \%$, multinational companies tend to allocate their corporate profits from other countries to our country. The increase in company profits due to the concept of Base Erosion and Profit Shifting (BEPS) will increase payable taxes and in turn will increase state revenue. For more details, the researchers made two estimates below. 


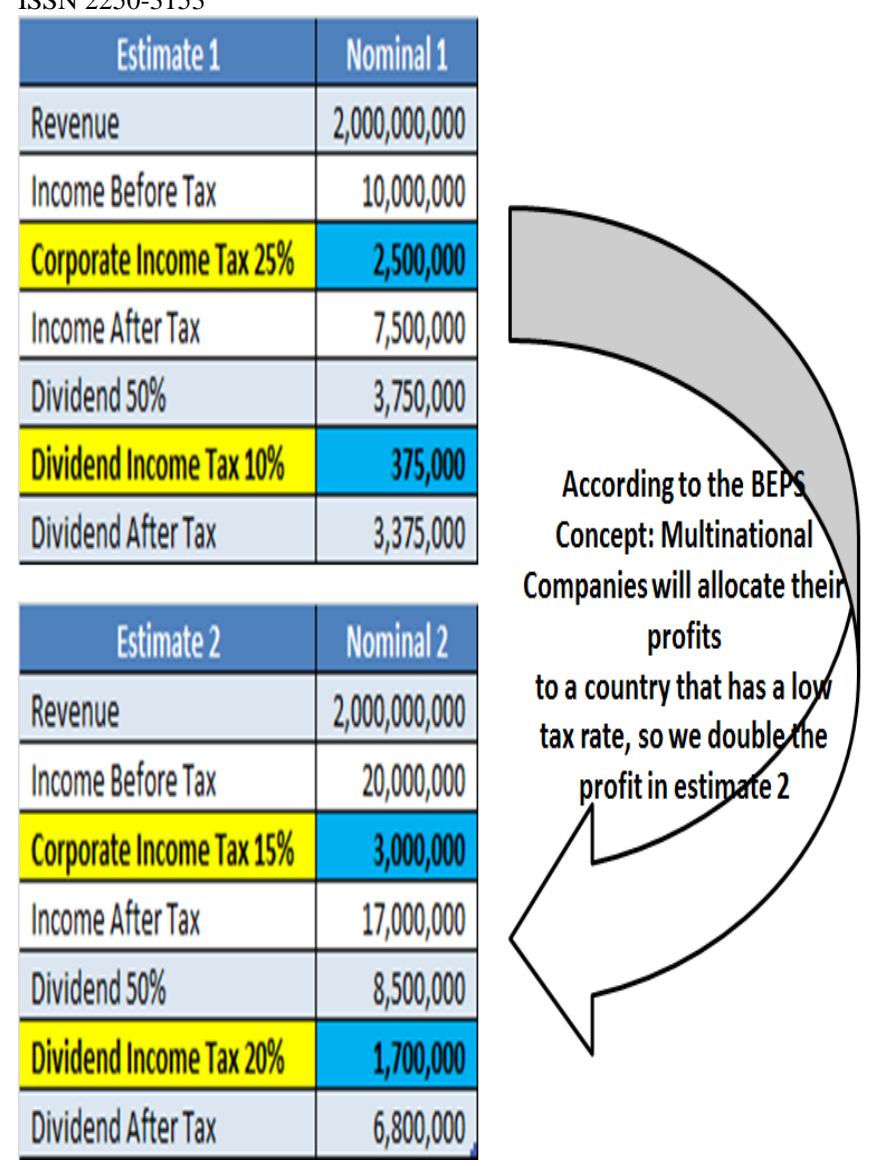

According to the two estimates above, it can be concluded that the tariff allocation actually increases the State's income. Therefore, researchers feel that Base Erosion and Profit Shifting (BEPS) is not completely bad or has a negative impact on State revenues. If the government can understand more deeply about Base Erosion and Profit Shifting (BEPS), it is possible to increase State revenue or have a positive impact on the State.

\section{CONCLUSIONS}

According to the statement, the researchers made several conclusions:

1. Base Erosion and Profit Shifting (BEPS) is a tax planning strategy that takes advantage of the gaps or weaknesses contained in the domestic tax law to eliminate or transfer these advantages to other countries that have lower tax rates.

2. To overcome the above impacts, the Organization for Economic Coorperation and Development (OECD) together with the G20 created a Base Erosion and Profit Shifting (BEPS) Action Plan to address many countries due to the problem of reducing state revenues from taxing aggressive tax regulations carried out by multinational companies (Arifin, 2014).
3. Even though the Organization for Economic Coordination and Development (OECD) and the G20 have taken precautions, there are still issues regarding aggressive tax avoidance, such as: the case of Google, Facebook, Starbucks and Amazon. The multinational company did not violate applicable laws, but carried out tax management which led to aggressive tax evasion. This is indeed more of a moral and ethical nature so that it is difficult to make rules and laws (PWC, 2013).

4. Company profits have a positive effect on State revenues, so that if the government can take advantage of Base Erosion and Profit Shifting (BEPS) in increasing company profits, it should increase State revenues.

\section{SUGGESTION}

According to conclusions, the researcher provides advice to the government to consider a tax rate policy that is in line with Base Erosion and Profit Shifting (BEPS) and still maintain State revenues.

\section{REFERENCES}

Arifin, N. Z. (2014). BEPS Dalam Kerangka Kerja Sama G20 Dan Implementasinya Kepada Indonesia. 1-27.

Johanna, I., \& Valderrama, M. (2020). INTERNATIONAL LAW AND PRACTICE BEPS principal purpose test and customary international law. May, 1-22. https://doi.org/10.1017/S0922156520000278

OECD/G20. (2016). OECD/G20 Base Erosion and Profit Shifting Project Limiting Base Erosion Involving Interest Deductions and Other Financial Payments Action 4. https://www.oecdilibrary.org/docserver/9789264268333en.pdf?expires $=1606830997 \&$ id $=\mathrm{id} \&$ acc name $=$ ocid 19 4738\&checksum=D5ACBD51FCF09DC751B9ACE1 CB66C036

OECD. (2015a). Action 15: A Mandate for the Development of a Multilateral Instrument on Tax Treaty Measures to Tackle BEPS.

OECD. (2015b). Action 2, Neutralising the Effects of Hybrid Mismatch Arrangements, 2015 Final Report. http://www.oecdilibrary.org/content/book/9789264241138en\%5Cnhttp://www.oecd-

ilibrary.org/docserver/download/2315291e.pdf?expires $=1448370288 \& \mathrm{id}=\mathrm{id} \&$ accname $=$ guest $\&$ checksum $=E 8$ 06EE292594C2E1BE1931C328D44191

OECD. (2015c). Addressing the Tax Challenges of the Digital Economy.

OECD. (2015d). BEPS ACTION 11: IMPROVING THE ANALYSIS OF BEPS. April.

OECD. (2015e). BEPS Action 3: Strengthening CFC Rules. May, 70.

OECD. (2015f). BEPS ACTION 7: PREVENTING THE 
ARTIFICIAL AVOIDANCE OF PE STATUS. May.

OECD. (2016a). BEPS Action 14 on More Effective Dispute

Resolution Mechanisms PEER REVIEW

DOCUMENTS (Issue October).

http://www.oecd.org/tax/beps/beps-action-14-on-

more-effective-dispute-resolution-peer-review-

documents.pdf

OECD. (2016b). Mandatory Disclosure Rules, Action 12 -

2015 Final Report. In Mandatory Disclosure Rules,

Action 12 - 2015 Final Report.

https://doi.org/10.1787/9789264261600-ko

OECD. (2017a). BEPS Action 13 on Country-by-Country

Reporting peer review documents. February, 38.

http://www.oecd.org/tax/beps/beps-action-13-on-

country-by-country-reporting-peer-review-

documents.pdf

OECD. (2017b). BEPS Action 5 on Harmful Tax Practices: Transparency Framework. Peer Review Documents.

OECD. (2017c). BEPS Action 6 on Preventing the Granting of Treaty Benefits in Inappropriate Circumstances:

Peer Review Documents. May.

https://www.oecd.org/tax/treaties/beps-action-6-

preventing-the-granting-of-treaty-benefits-in-

inappropriate-circumstance-peer-review-

documents.pdf

OECD. (2018). BEPS Actions 8 - 10 Financial-transactions. $1-43$.

PWC. (2013). In today's world, aggressive tax avoidance is the new tax evasion. July.

Rakhmindyarto. (2013). Base Erosion and Profit Shifting ( BEPS ): Aktivitas Ekonomi Global dan Peran OECD. Artikel Dan Opini Badan Kebijakan Fiskal. 